Univerzitet u Beogradu
Poljoprivredni fakultet
Institut za poljoprivrednu tehniku
Naučni časopis
POLJOPRIVREDNA TEHNIKA
Godina XLVI
Broj 3., 2021.
Strane: $61-73$

\title{
GLOBAL MAPPER 15.0: A COMPARATIVE SOFTWARE TOOL IN THE DESIGN OF OPEN CHANNEL DRAINAGE SYSTEMS
}

\author{
Maxwell Chikwue $^{1}$, Chumaraoke Njoku ${ }^{1}$, Nnaemeka Nwakuba* ${ }^{1}$, \\ Patrick Ezedozie $^{1}$, Okay Okorafor ${ }^{1}$ \\ Department of Agricultural \& Bioresources Engineering, School of Engineering \& \\ Engineering Technology, Federal University of Technology Owerri, Nigeria.
}

Abstract: This research aimed at computing peak flow discharge using state-of-theart technology for watershed analysis to design a suitable open channel to minimize the effects of flood hazard during and after rainfall in an environment. A comprehensive topographical survey data obtained by Shuttle Radar Topographic Mission was employed in this study. The result of the survey shows that both the maximum and minimum elevation at $61.9 \mathrm{~m}$ and $51.1 \mathrm{~m}$, respectively, and the mean slope of the area was 0.012. Watershed analysis of the study area was carried out using the Global Mapper15.0. The result shows that the parameters obtained such as the mean area of the sub-catchments is $1.43 \mathrm{ha}$, the mean length of channel flow is $99.33 \mathrm{~m}$, the mean length of overland flow is $111.81 \mathrm{~m}$, mean upstream elevation for overland flow is $63.30 \mathrm{~m}$, mean downstream elevation for overland flow is $62.37 \mathrm{~m}$ and mean downstream elevation for channel flow is $61.12 \mathrm{~m}$. The intensity duration frequency curve of the catchment was developed and a return period of 25 years was used to obtain an average rainfall intensity of $218.81 \mathrm{~mm} / \mathrm{hr}$. The peak discharge was obtained as $2.01 \mathrm{~m}^{3} / \mathrm{s}$ using rational formula due to the area of the watershed being less than 80 hectares. Finally, several design parameters for the modeled rectangular channel were calculated. The result indicated that the width of the channel is $0.80 \mathrm{~m}$ and the depth of the channel is 1.0 $\mathrm{m}$. The developed modeled channel has a design capacity of $2.03 \mathrm{~m}^{3} / \mathrm{s}$ which is greater than watershed peak discharge $2.01 \mathrm{~m}^{3} / \mathrm{s}$. The size of the modeled channel was compared with the size of the existing channel and the result revealed that the existing drain was insufficient to carry the discharge from the catchment area due to its design capacity of $0.91 \mathrm{~m}^{3} / \mathrm{s}$.

\footnotetext{
*Corresponding Author. E-mail: nrnwakuba@gmail.com
} 
It is recommended that the dimension of the existing drain should be increased to meet with the dimension of the modeled drain and a discharge point (safe outlet) should be provided.

Key words: watershed, peak flow, Global mapper 15.0, open channel

\section{INTRODUCTION}

Flood menace in Nigeria has become a normal and recurring phenomenon that sometimes has devastating impacts on human livelihoods and infrastructural development. This causes great concern in our immediate environment and country at large. A food is defined as an overflow of water that submerges usually dry land. A flood is defined as a covering by water of land not normally covered by water [1]. It can be caused by some factors such as rapid population growth, poor governance, poor drainage facilities and decaying infrastructures, poor practice of dumping waste/refuse. During heavy or long-duration rainfall events Eziobodo community experiences flood to a great extent especially along Federal University of Technology, Owerri (FUTO) Road. The existing drainage capacity provided along the road is not adequate, leading to stagnation of surface runoff for some period leading to flooding. The drainage system is covered with water in such a way that the drainage becomes invincible to the eye of those walking or driving along the road, this causes some motorcycles to fall inside those drains thereby making these individuals sustain injuries. The overtopping of water in the drains could be as a result of poor planning and design of the drainage system. For a drainage facility to be termed as poor it simply means that the drainage facility doesn't serve its required purpose. This could be as a result of wrong selection of the dimensions of the drain due to faulty mathematical equations used during the design or inaccurate hydrological studies of the area or some human activities such as dumping of refuse in the drains which hinders the free flow of water. This research aims at computing peak flow discharge using state-of-the-art technology for watershed analysis to design proper drain sizes and slopes to minimize the effects of flood hazards during and after rainfall events.

A watershed is defined as an area of land in which all of the incoming precipitation drains to the same body of water as a result of its topography [2]. In solving flood problems, watershed analysis can be employed through the use of remote sensing and GIS. One greater advantage of this is the ability to use GIS, which is a set of computerized tools for digital data processing, analysis, storage, retrieval and display of geographically referenced spatial information together with their attributes [3]. Watershed analysis refers to the process of using digital elevation models (DEM) and raster data operations to delineate watersheds and to derive catchment areas. from the flood affected catchment area using ArcGIS software, a geographic information system (GIS) software of which in this research was Global Mapper15.0 because it is more dedicated to watershed analysis due to its features.

This work aims to estimate the peak discharge of the affected catchment or watershed area which can be used to design a drainage system and compare the design dimensions with the already existing drainage channels in the catchment area. 
To achieve the research aim, the specific objectives of the study shall include: carrying out a topographical survey of the area of study, carrying out watershed analysis of the selected catchment using Global Mapper15.0, carrying out rainfall analysis of the selected catchment, using Kerby-Kirpich formula to determine the time of concentration, using the rational formula in calculating discharge to obtain a result for smaller watershed areas, using the obtained peak discharge to determine the dimensions of the drain using open channel design equations, measuring the dimensions of the drain already existing in the affected area and compare with the calculated dimensions.

\section{MATERIAL AND METHODS}

The following materials were used for this research are:

- Digital imagery of the catchment area

- Shuttle Radar Topographic Mission (SRTM) data of the catchment area

- Intensity-Duration-Frequency Curve of the catchment area

- Global Mapper15 (GIS Software).

The following entails methods used in this research;

- Watershed analysis using Global Mapper GIS Software

- Kerby-Kirpich formula to calculate the time of concentration,

- Intensity-duration-frequency Curve used to obtain rainfall intensity,

- Rational formula to calculate peak discharge,

- Design equations to calculate dimension of an open channel

\section{Study Area Description}

The study area is Eziobodo community, which is one of the host communities of the Federal University of Technology, Owerri (FUTO), located in Owerri-West local Government Area $\left(5.3669^{\circ} \mathrm{N}, 7.0042^{\circ} \mathrm{E}\right)$, of Imo State, Nigeria. Eziobodo is an Igbospeaking community with a population of over 15,000 locals (2006 census). It is geospatially located in Universal Transverse Mercator (UTM) projected coordinate system, Zone 32N in datum WGS84 at coordinate 278835.69 East and 593603.73 N, 279285.77 Easting and 594211.05 Northing, 278129.98 Easting and 594959.76 Northing.

\section{Watershed analysis using Global Mapper GIS Software}

This software was primarily used to obtain areas of sub-catchments, upstream elevation along the main channel, downstream elevation along the main channel, upstream elevation along the overland, downstream elevation along the overland, length of overland and length of the channel. These parameters were obtained when the software was supplied with the SRTM data of the study area for the watershed analysis and calculate the time of concentration using the Kerby-Kirpich formula. 


\section{Kerby-Kirpich formula}

The Kerby-Kirpich formula for estimating time of concentration (Tc) is applied to watersheds with areas ranging from 65 hectares to 38,850 hectares, main channel lengths between $1600 \mathrm{~m}$ and $80 \mathrm{~km}$ [4]. This method was used for obtaining the time of concentration for each of the sub-catchments, expressed by eq. (1) as:

$$
\mathrm{T}_{\mathrm{c}}=\mathrm{T}_{\mathrm{ov}}+\mathrm{T}_{\mathrm{ch}}
$$

Where: $\mathrm{T}_{\mathrm{c}}=$ time of concentration, minutes;

$\mathrm{T}_{\mathrm{ov}}=$ overland flow time, minutes;

$\mathrm{T}_{\mathrm{ch}}=$ channel flow time, minutes

\section{The Kerby Method}

In small watersheds overland flow is an important component of overall travel time [5]. The Kerby equation is expressed as:

$$
\mathrm{T}_{\mathrm{ov}}=\mathrm{K}(\mathrm{L} \times \mathrm{N})^{0.467} \times \mathrm{S}^{-0.235}
$$

Where: $\mathrm{T}_{\mathrm{ov}}=$ overland flow time of concentration, minutes; $\mathrm{K}=\mathrm{a}$ unit's conversion constant, $\mathrm{K}=1.44 ; \mathrm{L}=$ the overland-flow length, meters; $\mathrm{N}=$ a dimensionless retardance constant, $\mathrm{N}=0.3 ; \mathrm{S}=$ the dimensionless slope of terrain conveying the overland flow

\section{The Kirpich Method}

For channel-flow component of runoff, the Kirpich equation is applied thus to estimate the channel flow time [5]:

$$
\mathrm{T}_{\mathrm{ch}}=\mathrm{K} \times \mathrm{L}^{0.770} \times \mathrm{S}^{-0.385}
$$

Where: $\mathrm{T}_{\mathrm{ch}}=$ channel flow time, minutes; $\mathrm{K}=\mathrm{a}$ unit's conversion constant, $\mathrm{K}=0.0195$; $\mathrm{L}=$ the channel flow length, meters; $\mathrm{S}=$ the dimensionless main-channel slope.

\section{Intensity Duration Frequency Curve}

The time of concentration obtained from the use of kerby-kirpich formula was used to obtain corresponding rainfall intensity using the IDF Curve of the catchment area. The rainfall intensity was obtained based on the design return period of 25 years for drain channels.

\section{Rational formula}

This formula is appropriate for urban and rural watersheds less than 200 acres (80 hectares) with generally uniform surface cover and topography that is best suited for the catchment area [5]. This formula is used only to compute peak runoff rates.

The area of the sub-catchments obtained from watershed analysis and the rainfall intensity obtained from the intensity-duration-frequency curve were used to estimate the peak discharge rate using the rational formula, given as: 


$$
\mathrm{Q}=\frac{\mathrm{CIA}}{\mathrm{Z}}
$$

Where: $\mathrm{Q}$ and $\mathrm{C}$ are the peak discharge rate $\left(\mathrm{m}^{3} / \mathrm{s}\right)$ and runoff coefficient, respectively;

$\mathrm{I}=$ average rainfall Intensity $(\mathrm{mm} / \mathrm{hr})$;

$\mathrm{A}=$ drainage area (ha);

$\mathrm{Z}=$ conversion factor, 360 for metric.

\section{Open channel design}

The design of the open channel considered the bottom-width (b); depth of flow (d), velocity of flow (v) and the anticipated discharge from the selected channels. It also comprises of the sectional area (A), wetted perimeter $(\mathrm{P})$, the hydraulic radius $(\mathrm{R})$ and the Manning's velocity (V). However, for rectangular channel, the cross-sectional area is given as:

$$
\mathrm{A}=\mathrm{bd}
$$

Where:

$\mathrm{A}=$ cross-sectional area, $\mathrm{m}^{2} ; \mathrm{b}=$ bottom width, $\mathrm{m} ; \mathrm{d}=$ depth of flow, $\mathrm{m}$

For rectangular channel; the wetted perimeter is estimated as:

$$
P=b+2 d
$$

Where:

$\mathrm{P}=$ wetted perimeter, $\mathrm{m}$.

The hydraulic radius of the channel is given as:

$$
\mathrm{R}=\frac{\mathrm{A}}{\mathrm{P}}
$$

Where:

$\mathrm{R}=$ hydraulic radius, $\mathrm{m}$.

The velocity of flow is determined using the manning's formula, expressed in eq. (8) as:

$$
\mathrm{V}=\frac{1}{\mathrm{n}} \times \mathrm{R}^{\frac{2}{3}} \times \mathrm{S}^{\frac{1}{2}}
$$

Where:

$\mathrm{V}=$ velocity of flow, $\mathrm{m} / \mathrm{s} ; \mathrm{n}=$ Manning's roughness coefficient; $\mathrm{S}=$ bed slope of channel.

The bed slope is expressed as:

$$
\mathrm{S}=\frac{\Delta \mathrm{H}}{\mathrm{L}_{\mathrm{c}}}
$$


Where:

$\Delta \mathrm{H}=$ difference between the highest and lowest elevation (m); $\mathrm{L}_{\mathrm{c}}=$ length of channel (m).

The discharge capacity, $Q_{c}$ of the channel is given by:

$$
\mathrm{Q}_{\mathrm{c}}=\mathrm{AV}
$$

Where:

$\mathrm{Q}_{\mathrm{c}}=$ Discharge capacity of channel, $\mathrm{m}^{3} / \mathrm{s}$.

\section{Design dimensions}

The adequate dimensions of the drain as shown in Tab. 6 was obtained through the use of manning's formula using the open channel design equations, as well as trial-and-error approach.

\section{Hydraulic Analysis \\ Rectangular section}

$\mathrm{b}=0.80$ (assumed), $\mathrm{d}=0.83$ (assumed), $\mathrm{S}=0.012, \mathrm{n}=0.015\left(\right.$ Tab. 7), $\mathrm{Q}_{\mathrm{p}}=2.01 \mathrm{~m}^{3} / \mathrm{s}$ (Tab. 5).

Area of channel, $\mathrm{A}_{\mathrm{c}}=\mathrm{b} \times \mathrm{d}=0.80 \times 0.83=0.664 \mathrm{~m}^{2}$

Wetted perimeter, $P_{w}=b+2 d=0.80 \times(2 \times 0.83)=2.460 \mathrm{~m}$

Hydraulic Radius, $\mathrm{R}_{\mathrm{h}}=\frac{\mathrm{A}_{\mathrm{c}}}{\mathrm{P}_{\mathrm{w}}}=\frac{0.664}{2.460}=0.270 \mathrm{~m}$

Velocity of flow, $\mathrm{V}_{\mathrm{f}}=\frac{1}{\mathrm{n}} \times \mathrm{R}^{\frac{2}{3}} \times \mathrm{S}^{\frac{1}{2}}=\frac{1}{0.015} \times(0.270)^{\frac{2}{3}} \times(0.012)^{\frac{1}{2}}=3.05 \mathrm{~m} / \mathrm{s}$

Discharge capacity of channel, $\mathrm{Q}=\mathrm{A}_{\mathrm{c}} \times \mathrm{V}_{\mathrm{f}}=0.664 \times 3.05=2.03 \mathrm{~m}^{3} / \mathrm{s}$

Assuming a freeboard of $20 \%$

Freeboard, $F=\frac{20 \times d}{100}=\frac{20 \times 0.83}{100}=0.17 \mathrm{~m}$

Hence Depth, $\mathrm{D}=\mathrm{d}+\mathrm{F}=0.83+0.17=1.0 \mathrm{~m}$

\section{RESULTS AND DISCUSSION}

\section{Topographical survey}

Fig. 1 illustrates the undulating topographic pattern of the study area, with a maximum and minimum elevation of $61,9 \mathrm{~m}$ and $51,1 \mathrm{~m}$, respectively.

A topographic survey was carried out along FUTO-Eziobodo road as shown in Tab. 1. The slope of the land area was obtained to be 0.012 and also used to generate the SRTM data for the study area. The global mapper 15.0 software was used to generate the different sub-catchments contributing to the flow-line that approaches FUTO road. It was used to estimate the area, length of channel $\left(\mathrm{L}_{\mathrm{ch}}\right)$, length of overland $\left(\mathrm{L}_{\mathrm{ov}}\right)$, upstream $\left(\mathrm{H}_{1}\right)$ and downstream $\left(\mathrm{H}_{2}\right)$ elevations for overland, respectively; and downstream elevation for channel $\left(\mathrm{H}_{3}\right)$ for all the sub-catchments as shown in Tab. 2. 


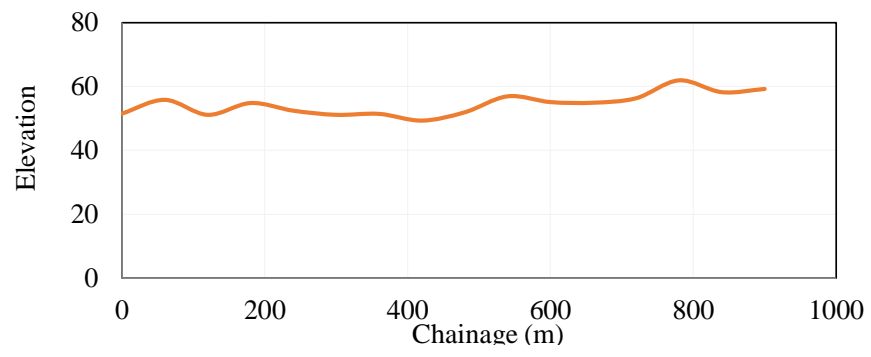

Figure 1. Topographic array of FUTO-Eziobodo road

Table 1. Topographical survey data along FUTO-Eziobodo road

\begin{tabular}{|l|l|l|c|}
\hline Chainages $(\mathrm{m})$ & Easting & Northing & Elevation $(\mathrm{m})$ \\
\hline $0+000$ & 278613.7 & 594251.2 & 51.5 \\
\hline $0+060$ & 278574.1 & 594302.0 & 55.8 \\
\hline $0+120$ & 278537.4 & 594352.1 & 51.1 \\
\hline $0+180$ & 278502.2 & 594395.9 & 54.8 \\
\hline $0+240$ & 279286.5 & 594439.1 & 52.4 \\
\hline $0+300$ & 278430.0 & 594484.6 & 51.1 \\
\hline $0+360$ & 278395.0 & 594528.9 & 51.4 \\
\hline $0+420$ & 278358.8 & 594584.9 & 49.3 \\
\hline $0+480$ & 278335.1 & 594629.5 & 51.9 \\
\hline $0+540$ & 278299.8 & 594683.0 & 56.9 \\
\hline $0+600$ & 278263.4 & 594731.5 & 55.1 \\
\hline $0+660$ & 278211.4 & 594776.1 & 54.9 \\
\hline $0+720$ & 278167.1 & 594816.4 & 56.3 \\
\hline $0+780$ & 278147.8 & 594875.6 & 61.9 \\
\hline $0+840$ & 278132.5 & 594934.3 & 58.2 \\
\hline $0+900$ & 278130.0 & 594959.8 & 59.2 \\
\hline
\end{tabular}

Table 2. Watershed analysis of the catchment area

\begin{tabular}{|l|l|l|l|l|l|l|}
\hline Sub-catchments (SC) & Area (ha) & $\mathrm{L}_{\mathrm{ch}}(\mathrm{m})$ & $\mathrm{L}_{\mathrm{ov}}(\mathrm{m})$ & $\mathrm{H}_{1}(\mathrm{~m})$ & $\mathrm{H}_{2}(\mathrm{~m})$ & $\mathrm{H}_{3}(\mathrm{~m})$ \\
\hline $\mathrm{SC}_{1}$ & 2.75 & 198.92 & 221.22 & 62.387 & 62.323 & 60.671 \\
\hline $\mathrm{SC}_{2}$ & 0.755 & 70.51 & 94.966 & 64.505 & 62.501 & 61.843 \\
\hline $\mathrm{SC}_{3}$ & 9.489 & 433.75 & 364.18 & 63.858 & 63.46 & 60.894 \\
\hline $\mathrm{SC}_{4}$ & 0.3429 & 69.352 & 53.424 & 62.279 & 60.305 & 59.671 \\
\hline $\mathrm{SC}_{5}$ & 0.4514 & 76.59 & 45.008 & 63.142 & 61.611 & 60.664 \\
\hline $\mathrm{SC}_{6}$ & 1.714 & 86.756 & 191.59 & 63.142 & 63.05 & 61.514 \\
\hline $\mathrm{SC}_{7}$ & 1.969 & 86.756 & 147.0 & 63.821 & 62.959 & 61.041 \\
\hline $\mathrm{SC}_{8}$ & 0.92 & 74.053 & 68.85 & 63.833 & 62.721 & 60.787 \\
\hline $\mathrm{SC}_{9}$ & 0.544 & 86.317 & 50.628 & 63.766 & 62.698 & 61.828 \\
\hline $\mathrm{SC}_{10}$ & 0.3223 & 98.689 & 39.031 & 63.877 & 62.516 & 61.845 \\
\hline $\mathrm{SC}_{11}$ & 0.571 & 77.425 & 71.339 & 63.83 & 62.909 & 61.227 \\
\hline $\mathrm{SC}_{12}$ & 1.571 & 98.33 & 125.39 & 62.922 & 62.896 & 60.604 \\
\hline $\mathrm{SC}_{13}$ & 0.3818 & 107.03 & 32.435 & 62.921 & 61.742 & 60.629 \\
\hline $\mathrm{SC}_{14}$ & 0.4583 & 79.672 & 48.543 & 62.935 & 62.246 & 60.943 \\
\hline $\mathrm{SC}_{15}$ & 0.4775 & 72.372 & 6.828 & 62.926 & 61.869 & 61.766 \\
\hline $\mathrm{SC}_{16}$ & 0.2217 & 72.372 & 28.85 & 62.601 & 62.048 & 61.959 \\
\hline
\end{tabular}


From Tab. 2, it is observed that increase in the area of the sub-catchment results in an increase in the length of channel and length of overland. The Sub-catchment 3 has the maximum area and also has the maximum length of channel and length of overland compared to other Sub-catchments.

\section{Intensity duration frequency (IDF) curve}

The intensity duration frequency (IDF) curve of the study area (Fig. 2) was generated using meteorological data from Nigerian Meteorological Agency and ArcGis Software.

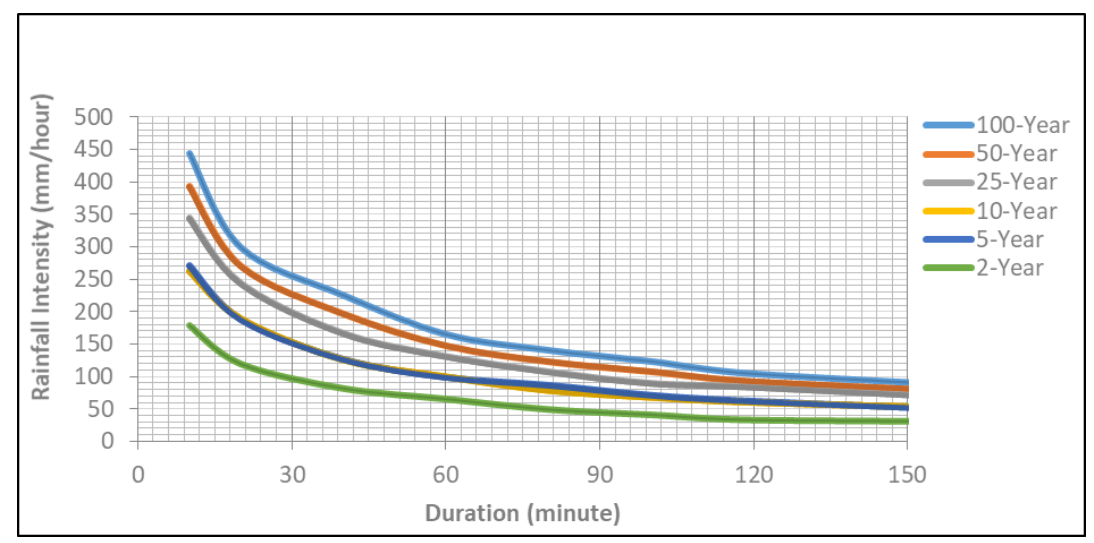

Figure 2: Intensity-Duration-Frequency (IDF) Curve for Owerri

The legend in the graph represents the return period (which is the average interval of time within which the magnitude of the rainfall event will be equaled or exceeded once) used in the design of hydraulic structures. In this research, a 25-year return period was adopted because, it is used for urban drainage works. From the IDF curve, it can be observed that the higher the time of concentration (duration) the lesser the rainfall intensity.

\section{Time of concentration}

The time of concentration $\left(\mathrm{T}_{\mathrm{c}}\right)$ for every sub-catchment as shown in Table and 3 was obtained by summing the time of overland flow $\left(\mathrm{T}_{\mathrm{ov}}\right)$ and time of channel flow $\left(\mathrm{T}_{\mathrm{ch}}\right)$. 
Table 3. Time of concentration (Tc) for different sub-catchments

\begin{tabular}{|c|l|l|l|}
\hline Sub-Catchment (SC) & $\mathrm{T}_{\mathrm{ov}}$ (mins) & $\mathrm{T}_{\mathrm{ch}}$ (mins) & $\mathrm{T}_{\mathrm{c}}$ (mins) \\
\hline $\mathrm{SC}_{1}$ & 64.3 & 8.2 & 72.5 \\
\hline $\mathrm{SC}_{2}$ & 13.8 & 4.4 & 18.2 \\
\hline $\mathrm{SC}_{3}$ & 72.4 & 12.3 & 84.7 \\
\hline $\mathrm{SC}_{4}$ & 13.7 & 2.3 & 16.0 \\
\hline $\mathrm{SC}_{5}$ & 15.6 & 1.6 & 17.2 \\
\hline $\mathrm{SC}_{6}$ & 33.0 & 7.2 & 40.1 \\
\hline $\mathrm{SC}_{7}$ & 19.5 & 4.8 & 24.3 \\
\hline $\mathrm{SC}_{8}$ & 16.4 & 2.0 & 18.4 \\
\hline $\mathrm{SC}_{9}$ & 18.5 & 1.9 & 20.4 \\
\hline $\mathrm{SC}_{10}$ & 19.2 & 1.6 & 20.7 \\
\hline $\mathrm{SC}_{11}$ & 17.7 & 3.2 & 19.9 \\
\hline $\mathrm{SC}_{12}$ & 48.5 & 1.0 & 52.2 \\
\hline $\mathrm{SC}_{13}$ & 21.0 & 1.6 & 22.0 \\
\hline $\mathrm{SC}_{14}$ & 19.4 & 0.4 & 20.9 \\
\hline $\mathrm{SC}_{15}$ & 16.4 & 2.4 & 16.8 \\
\hline $\mathrm{SC}_{16}$ & 19.1 & & 21.5 \\
\hline
\end{tabular}

From Tab. 3, it can be observed that $\mathrm{SC}_{3}$ has the highest $\mathrm{T}_{\text {ov }}$ of 72.4 mins, because of the magnitude of its $\mathrm{L}_{\mathrm{ov}}$ and $\mathrm{SC}_{4}$ has the lowest $\mathrm{T}_{\mathrm{ov}}$ of $13.7 \mathrm{mins}$ due to its $\mathrm{L}_{\mathrm{ov}}$. That is, the greater the $\mathrm{L}_{\mathrm{ov}}$, the greater the $\mathrm{T}_{\mathrm{ov}}$. The $\mathrm{SC}_{3}$ has the highest $\mathrm{T}_{\mathrm{ch}}, 84.7$ mins because of the magnitude of its $\mathrm{L}_{\mathrm{ch}}$ and $\mathrm{SC}_{15}$ has the lowest $\mathrm{T}_{\mathrm{ch}}, 0.4$ mins due to its $\mathrm{L}_{\mathrm{ch}}$. That is, the greater the $\mathrm{L}_{\mathrm{ch}}$, the greater the $\mathrm{T}_{\mathrm{ch}}$. Also, $\mathrm{SC}_{3}$ has the highest $\mathrm{T}_{\mathrm{c}}, 84.7$ mins because of the magnitude of its catchment area and Sub-catchment 4 has the lowest $\mathrm{T}_{\mathrm{c}}, 16.0$ due to its small catchment area.

\section{Rainfall intensity}

The time of concentration for each of the sub-catchment in Tab. 3 was used to obtain the corresponding intensity of rainfall $(\mathrm{mm} / \mathrm{hr}$.) as shown in Tab. 4 , for 25 years return period from the IDF curve shown in Fig. 2.

Table 4. Rainfall intensity using $\mathrm{T}_{\mathrm{c}}$ for each sub-catchment on IDF curve

\begin{tabular}{|c|c|c|}
\hline Sub-catchment (SC) & $\mathrm{T}_{\mathrm{c}}(\mathrm{mins})$ & Rainfall intensity, I (mm/hr.) \\
\hline $\mathrm{SC}_{1}$ & 72.5 & 115 \\
\hline $\mathrm{SC}_{2}$ & 18.2 & 244 \\
\hline $\mathrm{SC}_{3}$ & 84.7 & 106 \\
\hline $\mathrm{SC}_{4}$ & 16.0 & 275 \\
\hline $\mathrm{SC}_{5}$ & 17.2 & 270 \\
\hline $\mathrm{SC}_{6}$ & 40.1 & 163 \\
\hline $\mathrm{SC}_{7}$ & 24.3 & 220 \\
\hline $\mathrm{SC}_{8}$ & 18.4 & 242 \\
\hline $\mathrm{SC}_{9}$ & 20.4 & 248 \\
\hline $\mathrm{SC}_{10}$ & 20.7 & 245 \\
\hline $\mathrm{SC}_{11}$ & 19.9 & 250 \\
\hline $\mathrm{SC}_{12}$ & 52.2 & 140 \\
\hline $\mathrm{SC}_{13}$ & 22.0 & 230 \\
\hline $\mathrm{SC}_{14}$ & 20.9 & 240 \\
\hline $\mathrm{SC}_{15}$ & 16.8 & 270 \\
\hline $\mathrm{SC}_{16}$ & 21.5 & 243 \\
\hline & & \\
\hline & & \\
\hline
\end{tabular}




\section{Sub-catchments discharge}

The discharge of the sub-catchments (Tab. 5) was obtained using the rational formula. The runoff coefficient (C), 0.4 was selected based on the type of drainage area.

The total discharge from the sub-catchments was obtained to be $4.02 \mathrm{~m}^{3} / \mathrm{s}$ (Tab.5.) and the total peak design discharge was divided into two to obtain $2.01 \mathrm{~m}^{3} / \mathrm{s}$, which was used to design for the open channel that should be provided on both sides of the road.

Table 5. Design discharge for each of the sub-catchment

\begin{tabular}{|l|l|l|l|l|}
\hline Sub-catchment (SC) & $\begin{array}{l}\text { Runoff } \\
\text { Coefficient, } \\
\mathrm{C}\end{array}$ & $\begin{array}{l}\text { Rainfall Intensity, I } \\
(\mathrm{mm} / \mathrm{hr} .)\end{array}$ & Area (ha) & $\begin{array}{l}\text { Discharge, Q } \\
\left(\mathrm{m}^{3} / \mathrm{s}\right)\end{array}$ \\
\hline $\mathrm{SC}_{1}$ & 0.4 & 115 & 2.75 & 0.35 \\
\hline $\mathrm{SC}_{2}$ & 0.4 & 244 & 0.755 & 0.20 \\
\hline $\mathrm{SC}_{3}$ & 0.4 & 106 & 9.489 & 1.12 \\
\hline $\mathrm{SC}_{4}$ & 0.4 & 275 & 0.3429 & 0.10 \\
\hline $\mathrm{SC}_{5}$ & 0.4 & 270 & 0.4514 & 0.14 \\
\hline $\mathrm{SC}_{6}$ & 0.4 & 163 & 1.714 & 0.31 \\
\hline $\mathrm{SC}_{7}$ & 220 & 1.969 & 0.48 \\
\hline $\mathrm{SC}_{8}$ & 0.4 & 242 & 0.92 & 0.25 \\
\hline $\mathrm{SC}_{9}$ & 0.4 & 248 & 0.544 & 0.15 \\
\hline $\mathrm{SC}_{10}$ & 0.4 & 245 & 0.3223 & 0.09 \\
\hline $\mathrm{SC}_{11}$ & 0.4 & 250 & 0.571 & 0.16 \\
\hline $\mathrm{SC}_{12}$ & 0.4 & 140 & 1.571 & 0.24 \\
\hline $\mathrm{SC}_{13}$ & 0.4 & 230 & 0.3818 & 0.10 \\
\hline $\mathrm{SC}_{14}$ & 0.4 & 240 & 0.4583 & 0.12 \\
\hline $\mathrm{SC}_{15}$ & 0.4 & 270 & 0.4775 & 0.14 \\
\hline $\mathrm{SC}_{16}$ & 0.4 & 243 & 0.2217 & 0.06 \\
\hline
\end{tabular}

\section{Design comparison}

The design parameters of the modeled channel shown in Tab. 6 were compared to the design parameter of the existing channel as shown in Tab. 8.

Table 6. Design parameters of the modeled rectangular drain

\begin{tabular}{|c|c|}
\hline Shape & Rectangular \\
\hline Width, b (m) & 0.80 \\
\hline Depth, d (m) & 0.83 \\
\hline Bed slope, S (\%) (Table 1) & 1.2 \\
\hline Area, $\mathrm{A}\left(\mathrm{m}^{2}\right)$ & 0.664 \\
\hline Wetted perimeter, $\mathrm{P}(\mathrm{m})$ & 2.460 \\
\hline Hydraulic radius, $\mathrm{R}(\mathrm{m})$ & 0.270 \\
\hline Manning's coefficient, $\mathrm{n}$ & 0.015 \\
\hline Velocity of flow $(\mathrm{m} / \mathrm{s})$ & 3.05 \\
\hline Peak discharge, $\mathrm{Q}\left(\mathrm{m}^{3} / \mathrm{s}\right)$ & 2.03 \\
\hline Total depth, D (m) & 1.0 \\
\hline Freeboard $(20 \%)$ & 0.17 \\
\hline
\end{tabular}


Table 7: Manning's roughness coefficient, (n), [6]

\begin{tabular}{|l|c|}
\hline Type of gutter or pavement & Manning's, $\mathrm{n}$ \\
\hline Concrete gutter, troweled finish & 0.012 \\
\hline Asphalt pavement: smooth texture & 0.013 \\
\hline Asphalt pavement: rough texture & 0.016 \\
\hline Concrete gutter with asphalt pavement: smooth texture & 0.013 \\
\hline Concrete gutter with asphalt pavement: rough texture & 0.015 \\
\hline Concrete pavement: float finish & 0.014 \\
\hline Concrete pavement: broom finish & 0.016 \\
\hline $\begin{array}{l}\text { Note: For gutters with a small slope or where sediment may accumulate, increase n- } \\
\text { values by 0.02(USDOT, FHWA, 2001). }\end{array}$ \\
\hline
\end{tabular}

Table 8. Comparison of channel along FUTO-Eziobodo road

\begin{tabular}{|l|l|l|l|}
\hline Existing Channel Parameters & Modeled Channel Parameters \\
\hline Shape & Rectangular & Shape & Rectangular \\
\hline Width $(\mathrm{m})$ & 0.65 & Width $(\mathrm{m})$ & 0.92 \\
\hline Depth $(\mathrm{m})$ & 0.63 & Depth $(\mathrm{m})$ & 1 \\
\hline Bed Slope $(\%)$ & 0.86 & Bed Slope $(\%)$ & 1.2 \\
\hline Peak Discharge $(\mathrm{Q})\left(\mathrm{m}^{3} / \mathrm{s}\right)$ & 0.91 & Peak Discharge $(\mathrm{Q})\left(\mathrm{m}^{3} / \mathrm{s}\right)$ & 3.11 \\
\hline
\end{tabular}

The data in Tab. 8 shows that the existing channel capacity did not meet up to the discharge from the catchment area with the existing channel capacity of $0.91 \mathrm{~m}^{3} / \mathrm{s}$ whereas the discharge from the catchment area was $2.01 \mathrm{~m}^{3} / \mathrm{s}$.

The insufficiency of the existing drain results to the cause of flooding during rainfall events because the drain section fills up easily and begins to overflow to adjoining areas of the catchment and also the abrupt termination of the existing channel without an outlet also resulted in the flow building up in the channel which overflows onto the surroundings the channels are overtopped.

\section{CONCLUSIONS}

In this work which was aimed at computing peak flow discharge using state-of-the-art technology for watershed analysis to design a suitable open channel to minimize the effects of flood hazard during and after rainfall in an environment. The following conclusions are depicted:

- The topographical survey of the study area was carried out; the results of the survey show that maximum and minimum elevations obtained were 61.9 and $51.1 \mathrm{~m}$, respectively; whereas the mean slope of the area is $1.2 \%$.

- Watershed analysis of the study area was also carried out using the Global Mapper 15.0 tool. From the results, the parameters obtained such as the mean area of the subcatchments, mean length of channel flow, mean length of overland flow, mean upstream elevation for overland flow, mean downstream elevation for overland flow, and mean downstream elevation for channel flow were 1.43 ha, $99.33 \mathrm{~m}, 111.81 \mathrm{~m}$, $63.30 \mathrm{~m}, 62.37 \mathrm{~m}$ and $61.12 \mathrm{~m}$, respectively.

- The intensity duration frequency curve of the study area was developed. The average rainfall intensity of all the sub-catchments using a return period of 25 years was obtained as $218.81 \mathrm{~mm} / \mathrm{hr}$. 
- The Kerby-Kirpich formula was used to obtain the time of concentration of all the sub-catchments. The result shows that the meantime of concentration is 30.4 mins.

- Furthermore, the results from the hydrological analysis of the study area were used to determine the peak discharge of $2.01 \mathrm{~m}^{3} / \mathrm{s}$ on both side of the catchment using the rational formula.

- Also, the hydraulic analysis was carried out using the peak discharge of $2.01 \mathrm{~m}^{3} / \mathrm{s}$ to design for a rectangular channel section having a width of $0.80 \mathrm{~m}$ and a depth of 1.0 $\mathrm{m}$ with a bed slope of 0.012 .

Finally, the comparisons between the two channels show that the existing channel capacity did not meet up to the discharge from the catchment area with the existing channel capacity of $0.91 \mathrm{~m}^{3} / \mathrm{s}$ while the discharge from the catchment area was 2.01 $\mathrm{m}^{3} / \mathrm{s}$. Therefore, the dimensions of the existing channel are insufficient and should be modified to fulfil its purpose of channeling water without overtopping.

\section{REFERENCES}

[1] Directive 2007/60/EC of the European Parliament and of the council of 23 October 2007 on the Assessment and Management of Flood Risks. pp. 27-34.

[2] Edwards, P., Williard, K., Schnoonover, J. 2015. Fundamentals of Watershed Hydrology. Universities Council on Water Resources Journal of Contemporary Water Research \& Education, (154), pp. 3-20.

[3] Musa, A. 2001. Application of GIS in planning Field. A paper presented at the Department of Urban and Regional planning, FUT, Yola.

[4] Roussel, Meghan, Thompson, B. \& Cleveland., 2005. Time-Parameter Estimation for Applicable Texas Watersheds. Texas, U.S.A.

[5] Texas Department of Transportation. 2004. Hydraulic Design Manual. Texas, U.S.A.

[6] Texas Department of Transportation. 2016. Hydraulic Design Manual. Revised Edition. Texas, U.S.A.

\section{GLOBAL MAPPER 15.0: UPOREDNI PROGRAMSKI ALAT ZA DIZAJN OTVORENIH KANALSKIH SISTEMA ZA ODVODNJAVANJE}

\section{Maxwell Chikwue, Chumaraoke Njoku, Nnaemeka Nwakuba, Patrick Ezedozie and Okay Okorafor}

Department of Agricultural \& Bioresources Engineering, School of Engineering \& Engineering Technology, Federal University of Technology Owerri, Nigeria.

Sažetak: Istraživanje ima za cilj izračunavanje najvećeg protoka pomoću najsavremenije tehnologije za analizu sliva kako bi se dizajnirao odgovarajući otvoreni kanal i umanjili efekti opasnosti od poplave tokom i nakon kiša u okruženju.

U ovoj studiji korišćeni su sveobuhvatni podaci o topografskim istraživanjima dobijeni od topografske misije Shuttle Radar Topographic Mission. 
Rezultat istraživanja pokazuje da su maksimalna i minimalna nadmorska visina od $61,9 \mathrm{~m}$, odnosno $51,1 \mathrm{~m}$, a srednji nagib područja bio je 0,012 . Analiza sliva istraživanog područja izvršena je pomoću programa Global Mapper verzija 15.0.

Rezultat pokazuje dobijene parametre: srednja površina podsliva 1,43 ha, srednja dužina protoka kanala 99,33 m, srednja dužina kopnenog toka 111,81 m, srednja nadmorska visina nadzemnog toka $63,30 \mathrm{~m}$, srednja nadmorska visina za kopneni tok je $62,37 \mathrm{~m}$, a srednja nadmorska visina za protok kanala je $61,12 \mathrm{~m}$.

Kriva frekvencije trajanja intenziteta padavina u slivu je razvijena i upotrebljen je kontrolni period od 25 godina da bi se dobio prosečan intenzitet padavina od 218,81 $\mathrm{mm} / \mathrm{sat}$. Najveći protok je dobijen kao $2,01 \mathrm{~m}^{3} / \mathrm{s}$ koristeći racionalnu formulu zbog površine sliva manjeg od 80 ha.

Konačno, izračunato je nekoliko projektnih parametara za model pravougaonog kanala. Rezultat je pokazao da je širina kanala $0,80 \mathrm{~m}$, a dubina kanala $1,0 \mathrm{~m}$. Razvijeni model kanala ima projektni kapacitet od $2,03 \mathrm{~m}^{3} / \mathrm{s}$ što je veća vrednost od najvećeg protoka sliva od $2,01 \mathrm{~m}^{3} / \mathrm{s}$.

Veličina modela kanala upoređena je sa veličinom postojećeg kanala, a rezultat je pokazao da postojeći profil odvoda nije dovoljan za odvođenje vode iz sliva zbog njegovog manjeg projektnog kapaciteta od $0,91 \mathrm{~m}^{3} / \mathrm{s}$.

Preporuka je da se dimenzija postojećeg kanala poveća tako da se zadovolji sa dimenzijom modelovanog odvoda kanala i obezbedi mesto ispuštanja vode (siguran izlaz).

Ključne reči: sliv, najveći protok, Global maper 15.0, otvoreni kanal

Prijavljen:

Submitted:

Ispravljen:

Revised:

Prihvaćen:

Accepted:
03.04.2021.

10.06.2021.

15.06.2021. 